\title{
SUPERHEROES, RESILIENCE AND COVID-19
}

\section{SUPERHEROES, RESILIENCIA Y COVID-19}

\author{
Palomar-Ciria, Nora'; Bello, Hugo J² \\ ${ }^{1}$ Psychiatry Service, Complejo Asistencial de Soria, Soria, Spain. \\ ${ }^{2}$ Department of Applied Mathematics, Universidad de Valladolid, Campus de Soria, Soria, Spain.
}

Recibido: 22/02/2021 | Revisado: 06/04/2021 | Aceptado: 26/05/2021

DOI: 10.15568/am.2021.813.cd01

Actual Med. 2021; 106(813): 222-223

\section{Cartas al editor}

\section{Dear editor,}

Batman lost his parents in a tragic assault. Katniss Everdeen lost his father in a mine accident and her mother suffered major depressive disorder during her childhood. Superman was abandoned on Earth. Harry Potter was adopted by his relatives, who neglected him after his parents were killed. Iron Fist lost his parents in a plane accident. Daredevil was blinded in an explosion. The list goes on: Catwoman, Luke Skywalker, Jessica Jones... There are few superheroes who do not rise from an humble or disadvantaged origin. In fact, approximately $50 \%$ had one parent murdered, $85 \%$ are orphans or have been abandoned and $29 \%$ had suffered from bullying $(1,2)$.

It is possible that tragic backstories motivate heroes to become paladins of justice and good. It is possible that they would never have become such heroes if the traumatic experience had not occurred. Maybe, these characters needed become heroes in order to overcome their traumas, some more successfully than others. This ability to adapt and recover from an adverse situation is called resilience and it is built in personal or cultural crisis. Resilience in superheroes often help them develop into what they are, and they are usually depicted as good and altruistic people. Some of this heroes may represent role models for children and youngers, which may promote resilience, especially in vulnerable children $(1,2)$.

Back to real world, since its declaration in march 2020, pandemic coronavirus disease 19 (COVID-19) has become a global health challenge that will have series mental health and psychological consequences. This disease has promoted multiple governmental responses worldwide in order to diminish its impact, though mental health cannot be overlooked as it is considered by some authors a following "second pandemic". In this line, mental health programs should be established to promote not only mental health, but also resilience (3).
The world looks now at healthcare workers. They put themselves on the line, while often ill-equipped and without enough support, risking their own lives to save and protect the lives of others. For them, COVID-19 pandemic represents a novel psychological trauma-related challenge. They are the ones that deal with the virus face to face, fighting its symptoms, consequences and outcomes, that include loss and death. It is safe to say that resilience plays a role in their ability to carry on working and living. Hence, resilience-building techniques, stress inoculations methods - that prepare for specific stressors they may face - and psychological training will help mitigate the impact the pandemic is generating in them (4).

Some would say that this pandemic has raised the best of people, solidarity - even heroism -, cohesion and resilience (5). So, if resilience is trained within the context of catastrophes or disasters, we hope all of us will come up from this pandemic strengthen. More so for healthcare workers, our contemporary superheroes - with their own traumas to deal with - who will inspire children of tomorrow. In this pandemic and the pandemics to come.

\section{BIBLIOGRAPHIC REFERENCES}

1. Jenkins L, Webb T, Browne N, Afifi AA, Kraus J. An Evaluation of the Motion Picture Association of America's Treatment of Violence in PG-, PG-13-, and R-Rated Films. Pediatrics. 2005; 115(5): e512-7.

2. Muller JN, Moroco A, Loloi J, Portolese A, Wakefield BH, King TS, et al. Violence Depicted in Superhero-Based Films Stratified by Protagonist/Antagonist and Gender. Cureus. 2020; 12(2): e6843

3. Choi KR, Heilemann MV, Fauer A, Mead M. A Second Pandemic: Mental Health Spillover from the novel Coronavirus 
(COVID-19). J Am Psychiatr Nurses Assoc. 2020; 26(4): 340-343.

4. Lupe SE, Keefer L, Szigethy E. Gaining resilience and reducing stress in the age of COVID-19. Curr Opin Gastroenterol. 2020; 36(4): 295-303.

5. Smith GD, Ng F, Ho Cheung Li W. COVID-19: Emerging compassion, courage and resilience in the face of misinformation and adversity. J Clin Nurs. 2020; 29(9-10): 1425-8.

\section{CONFLICT OF INTERESTS}

The authors of this article declare that they have no conflict of interest with respect to what is stated in this work.

\section{Si desea citar nuestro artículo:}

Palomar-Ciria N, Bello HJ. Superheroes, resilience and covid-19. Actual Med. 2021; 106(813): 222-223. DOI: 10.15568/ am.2021.813.cd01 